\title{
PRODUCTION OF HYIGH-PURITY ZINC SINGLE CRYSTALS BY VERTICAL DIRECTED CRYSTALLIZATION METHOD
}

\author{
A.P. Shcherban ${ }^{1}$, G.P. Kovtun ${ }^{1,2}$, D.A. Solopikhin ${ }^{1}$, Yu.V. Gorbenko ${ }^{1}$, T.Yu. Rudycheva, \\ D.G. Malykhin, I.V. Kolodiy', V.D. Virych ${ }^{1}$ \\ ${ }^{1}$ National Science Center "Kharkov Institute of Physics and Technology", \\ Kharkiv, Ukraine; \\ ${ }^{2}$ V.N. Karazin Kharkiv National University, Kharkiv, Ukraine \\ E-mail: shcherban@kipt.kharkov.ua
}

A seedless process has been developed to produce high-purity $\mathrm{Zn}$ single crystals by the method of vertical directed crystallization from a melt. The output of a single crystal structure is from 60 to $80 \%$. Crystals with different growth directions were obtained: [1015] and [0002]. The deviation angles of the growth direction plane relative to the normal to the axis of the sample are $0.5 \ldots 6^{\circ}$. Microhardness, crystalline perfection of single crystals and microstructure have been determined. The impurity composition of the start and end parts of single crystals produced from initial grades of zinc of various purities was studied. The developed process can be used to grow single crystals lowmelting metals, such as $\mathrm{Cd}, \mathrm{Pb}, \mathrm{Te}, \mathrm{In}, \mathrm{Bi}, \mathrm{Sn}$, etc.

PACS: $81.10 .-\mathrm{h}$

\section{INTRODUCTION}

Recently, the need for single crystals of metals for practical and research purposes has been increasing. For this reason, a new industry has increased - single crystal growing. Single crystals of metals and semiconductors are produced by growing from a melt mainly in three ways: vertical directed crystallization - the Bridgman method [1], pulling from a melt onto a seed - the Czochralski method [2, 3] and crucibleless melting - the Pfann method [4].

The history of the development of techniques for growing single crystals by the method of vertical directed crystallization totals about 100 years. The first papers on crystal growth by vertical directed crystallization (VDC) were those of Tamman (1923) [5].

In 1924, Obreimov I.V. and Shubnikov L.V. implemented the VDC method in which single crystals were grown in a vertical stationary tubular container cooled with compressed air [6].

Bridgman P. in 1925 made constructive changes to the proposed VDC method. In this method the container has become movable.

Stockbarger D. in 1937 introduced additional design changes to the Bridgman VDC process. A 2-section heater with a diaphragm in its middle is proposed here to provide a larger temperature gradient at the crystallization front. In 1925, Bridgman prepared single crystals of $\mathrm{Sn}, \mathrm{Cd}, \mathrm{Zn}, \mathrm{Sb}, \mathrm{Bi}$, and Te by the VDC method. Since then, researchers have been working both on improving technological methods for growing single crystals, and on achieving a perfect structure and quality of the producing single crystals.

The aim of the work is to develop a process for the production of high-purity bulk zinc single crystals by the VDC method without the use of seed. In this case, at the sharp end of the conical bottom of the crucible, after leaving the furnace, several crystals nucleate. During growth, one of them gradually occupies the entire cross section of the container.

\section{MATERIAL AND RESEARCH METHODS}

Two grades of metal were used as the initial material for producing high-purity zinc single crystals by the VDC method: metal of the industrial grade ZV0 (>99.995\%), and zinc produced by deep refining with the method of vacuum distillation $(>99.999 \%)[8,9]$.

Spontaneous directions of growth orientations in the produced $\mathrm{Zn}$ single crystals were determined, their structural perfection was studied, and the changes in the microhardness and impurity composition of the start and end parts of single crystals were ascertained.

Diffractometric studies of the samples were carried out on a DRON-2.0 X-ray diffractometer with copper $\mathrm{Co}-\mathrm{K} \alpha$ radiation using a Fe selectively absorbing filter. Diffracted radiation was detected by a scintillation detector. An analysis of crystallographic orientation (CGO) and crystal perfection was carried out from the butt-end part of the rods by the rotating crystal method.

Microhardness measurements were carried out on a PMT-3 instrument with a load of $20 \mathrm{~g}$. The microstructure was studied using an MMP-4 light microscope. To study the microstructure, we prepared thin sections by grinding and polishing according to the standard method, followed by etching in a reagent of the following composition: chromic anhydride - $10 \mathrm{~g}$, hydrochloric acid $-1 \mathrm{ml}$, water $-100 \mathrm{ml}$

The impurity composition of single crystals was determined by laser mass spectrometry using the mass spectrometer of EMAL-2 type. The random error of the analysis results is characterized by a relative standard deviation within $0.15 \ldots 0.30$.

\section{EXPERIMENTAL SECTION}

The process of growing crystals by the VDC method is carried out in special facilities in vacuum, inert atmosphere, hydrogen and in air. The Bridgman method is suitable for metals with a relatively low melting point and little chemical activity. These restrictions arise owing to the difficulty in selecting the material of the crucible-container. Crucibles made of graphite, quartz, 
aluminum oxide are commonly used. The great advantage of the Bridgman method is that it allows us to get crystals of large sizes.

Investigations of the process of producing zinc single crystals by the VDC method were carried out on a facility designed for growing gallium arsenide single crystals. The heat unit and mounting of this installation were modernized for the process of growing single crystals by the vertical Bridgman method. A special device was fabricated, the diagram of which is shown on Fig. 1.

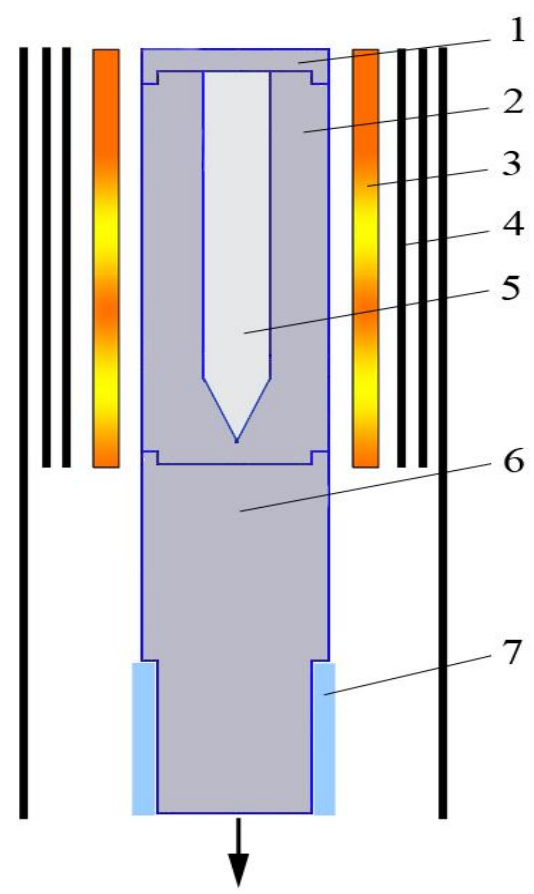

Fig. 1. Scheme of the device for growing Zn single crystals by the VDC method: 1 -cover; 2 - container for metal; 3 -heater; 4 -thermal screens; 5-metal;

6 - graphite adapter; 7 - cooled rod

A container with molten zinc was pulled down from the heater to a cold region, where, as it was pulled, a single-crystal structure of arbitrary orientation was formed.

To carry out the processes of directed crystallization of zinc, the special containers were made of high-purity dense graphite of MPG-7 grade. The impurity composition of such graphite is given in paper [7]. The containers were of conical shape at the bottom with an apex angle of 90 and $40^{\circ}$. Before use, the container was calcined at the temperature $\sim 1000{ }^{\circ} \mathrm{C}$ in a vacuum of $1 \ldots 3 \mathrm{~Pa}$ for half an hour. The crystals were grown with a crystallization rate from 0.63 to $0.21 \mathrm{~mm} / \mathrm{min}$ under a pressure in the apparatus chamber of about $1.7 \ldots 1.9 \mathrm{~atm}$ of pure argon. The temperature gradient at the crystallization front ranged from 18.7 to $23.3{ }^{\circ} \mathrm{C} / \mathrm{cm}$.

\section{RESULTS AND DISCUSSION}

Fig. 2 shows the diffraction patterns of two single crystals: (a) and (b).

The analysis of the diffraction patterns revealed that the crystals are almost of single-crystal structure with the growth direction [1015] (a) and [0002] (b), but there are also fine grains with a different orientation (in particular, the lines (0002) (a) and (1000) (b) are present on the diffraction patterns). It was found that the angle of deviation of the growth direction relative to the axis of the $\operatorname{rod}$ is $\alpha \approx 0.5^{\circ}$ for the single crystal (a) and $\alpha \approx 4^{\circ}$ for the single crystal (b).
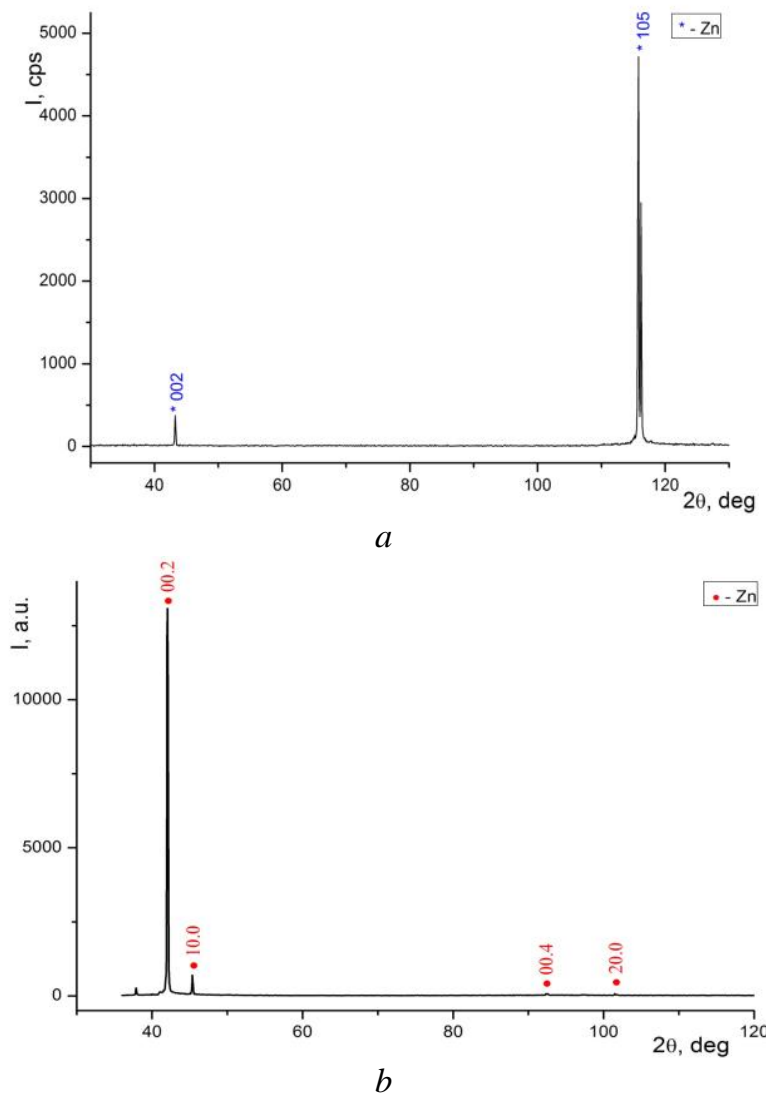

Fig. 2. Diffraction patterns of zinc single crystals

Table 1 shows the microhardness values and the total content of impurity elements for the start and end sections of single crystals produced from zinc of CV0 grade (crystal A) and distilled zinc (crystal B), and Table 2 shows the content of separate elements in the start and end sections of single crystals $\mathrm{A}$ and $\mathrm{B}$.

Table 1

The microhardness of zinc single crystals, $H_{\mu}\left(\mathrm{kg} / \mathrm{mm}^{2}\right)$ and their purity, $\%$

\begin{tabular}{|c|c|c|c|}
\hline \multicolumn{2}{|c|}{ Crystal A } & \multicolumn{2}{c|}{ Crystal B } \\
\hline $\begin{array}{c}\text { Start } \\
\text { section }\end{array}$ & $\begin{array}{c}\text { End } \\
\text { section }\end{array}$ & $\begin{array}{c}\text { Start } \\
\text { section }\end{array}$ & $\begin{array}{c}\text { End } \\
\text { section }\end{array}$ \\
\hline $44 \pm 2$ & $49 \pm 9$ & $45 \pm 2$ & $49 \pm 6$ \\
\hline$\sim 99,997$ & $\sim 99,995$ & $\sim 99,999$ & $\sim 99,998$ \\
\hline
\end{tabular}

It is seen (Table 1) that the microhardness in both crystals is higher in the end section, which is explained by the redistribution of most impurities to the end part of crystal (see Table 2). This is due to the fact that most impurity elements have equilibrium distribution coefficients in zinc $\mathrm{k}_{0}<1$. The exceptions are $\mathrm{Cu}$ and $\mathrm{Ag}$ impurities for which $\mathrm{k}_{0}>1: \mathrm{k}_{0}$ for $\mathrm{Cu}$ is $1.5, \mathrm{k}_{0}$ for $\mathrm{Ag}$ is 2.1 [10]. 
Table 2

Redistribution of impurity elements in zinc single crystals, $\times 10^{-4} \mathrm{wt} . \%$

\begin{tabular}{|c|c|c|c|c|}
\hline \multirow{2}{*}{ Element } & \multicolumn{2}{|c|}{ Crystal A } & \multicolumn{2}{c|}{ Crystal B } \\
\cline { 2 - 5 } & Start section & End section & Start section & End section \\
\hline $\mathrm{Al}$ & 2 & 4 & 0.1 & 0.05 \\
\hline $\mathrm{P}$ & $<0.3$ & 0.1 & 0.08 & 0.15 \\
\hline $\mathrm{Cl}$ & 0.7 & 1.2 & 0.3 & 0.45 \\
\hline $\mathrm{K}$ & 0.1 & 0.12 & 0.4 & 0.65 \\
\hline $\mathrm{Ca}$ & 0.5 & 0.65 & 0.5 & 0.2 \\
\hline $\mathrm{Fe}$ & 1 & 2 & 0.3 & 0.34 \\
\hline $\mathrm{Cu}$ & 6 & 5 & 0.23 & $<0.1$ \\
\hline $\mathrm{Br}$ & 3 & 4 & 1 & 13 \\
\hline $\mathrm{Ag}$ & 4 & 2 & 2.0 & $<0.1$ \\
\hline $\mathrm{Cd}$ & 6 & 10 & $<0.1$ & $<0.1$ \\
\hline $\mathrm{Sn}$ & 1 & 3 & $<0.1$ & $<0.1$ \\
\hline $\mathrm{Sb}$ & $<0.2$ & 0.4 & $<0.1$ & $<0.1$ \\
\hline $\mathrm{W}$ & $<0.5$ & 3 & $<0.1$ & $>99.998$ \\
\hline $\mathrm{Pb}$ & 4 & 99.995 & $>99.999$ & 0.2 \\
\hline $\mathrm{Zn} \%$ & $>99.997$ & & & \\
\hline
\end{tabular}

Fig. 3 shows a photograph of the microstructure of the end sections of zinc single crystal. The single-crystal structure of zinc is formed with distance from the start section of the ingot and amounts to $60 \ldots 80 \%$ of the crystal length.

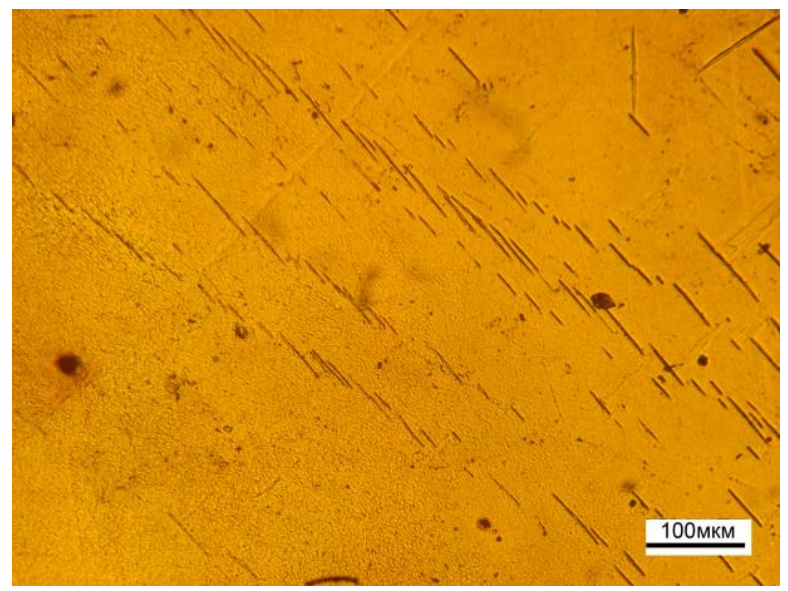

Fig. 3. The microstructure of the single-crystal part of the zinc crystal

By the developed method the high-purity single crystals of cadmium and lead were also obtained, which are in the process of studying their properties.

\section{CONCLUSIONS}

1. The process has been developed to produce highpurity $\mathrm{Zn}$ single crystals by the method of VDC from melt. The output of single crystal structure is from 60 to $80 \%$.

2. The spontaneous orientations of $\mathrm{Zn}$ single crystals close to the growth directions [1015] and [0002] are established. The angles of deviation of the growth direction relative to the axis of the samples are $0.5 \ldots 6^{\circ}$.

3. The microstructure and microhardness of the start and end sections of the grown crystals were ascertained. The microhardness of the end section of single crystals is higher in comparison with the microhardness of the start part of crystals, which is associated with the redis- tribution of most impurities to the end section of single crystals.

4. The content of impurities in the start and end sections of the grown zinc single crystals of various degrees of initial purity was determined.

\section{REFERENCES}

1. R.A. Laudise, R.L. Parker. Single crystal growth. M.: "Mir", 1974, 540 p.

2. D.T.J. Hurle. The Evolution And Modelling of The Czochralski Growth Technique // J. of Cryst. Growth. 1987, v. 85, p. 1-8.

3. G. Muller. The Czochralski Method - where we are 90 years after Jan Czochralski's invention // Cryst. Res. Technol. 2007, v. 42, N 12, p. 1150-1161.

4. W. Pfann. Zone Melting, M.: "Mir", 1970, 367 p.

5. G. Carpenter. Metallic Crystal // Physics Uspekhi. 1930, v. X, issue 5-6 (in Russian).

6. O.G. Kozlova. Crystal Growth / Edited by academician N.V. Belov. M.: Moscow State University Publishing House, 1967, 238 p.

7. V.K. Komar, V.M. Pusikov. $A^{I I} B^{V I}$ Single Crystals. Growth, Properties, Application. Kharkiv: State Scientific Institution "Institute of Single Crystals". 2002, 244 p.

8. A.P. Shcherban. Obtaining High Purity Metals For Low Background Scintillating Detectors of Rare Events // Problems of Atomic Science and Technology. Series "Vacuum, Pure Materials, Superconductors" (19). 2011, N 6(76), p. 3-9.

9. G.P. Kovtun, D.A. Solopikhin, A.P. Shcherban. Deep Refining of Fusible Metals By the Vacuum Distillation // "High Pure substances". Team of authors. M.: "Scientific World" Publishing House, 2018, Chapter 21, p. 494-513.

10. G.P. Kovtun, A.P. Shcherban, O.A. Datsenko. The Classification Behavior of Impurities in Zinc, Cadmium and Tellurium Under Purification By Crystallization // Problems of Atomic Science and Technology. Series "Vacuum, Pure Materials, Superconductors". 2004, N 6(14), p. 16-20. 


\title{
ПОЛУЧЕНИЕ ВЫСОКОЧИСТЫХ МОНОКРИСТАЛЛОВ ЦИНКА МЕТОДОМ ВЕРТИКАЛЬНОЙ НАПРАВЛЕННОЙ КРИСТАЛЛИЗАЦИИ
}

\author{
А.П. Щербань, Г.П. Ковтун, Д.А. Солопихин, Ю.В. Горбенко, Т.Ю. Рудычева, \\ Д.Г. Малыхин, И.В. Колодий, В.Д. Вирич
}

Разработан беззатравочный процесс получения высокочистых монокристаллов Zn методом вертикальной направленной кристаллизации (ВНК) из расплава. Выход монокристаллической структуры составляет от 60 до 80\%. Получены кристаллы с различными направлениями роста: [1015] и [0002]. Углы отклонения плоскости направления роста относительно нормали к оси образца составляют $0,5 \ldots 6^{\circ}$. Определены микротвердость, кристаллическое совершенство монокристаллов и микроструктура. Исследован примесный состав начальной и конечной частей монокристаллов, полученных из исходных марок цинка различной чистоты. Разработанный процесс может быть использован для выращивания легкоплавких металлов, таких как Сd, $\mathrm{Pb}, \mathrm{Te}, \mathrm{In}, \mathrm{Bi}, \mathrm{Sn}$ и др.

\section{ОТРИМАННЯ ВИСОКОЧИСТИХ МОНОКРИСТАЛІВ ЦИНКУ МЕТОДОМ ВЕРТИКАЛЬНОЇ НАПРАВЛЕНОЇ КРИСТАЛІЗАЦЇ̈}

\author{
О.П. Щербань, Г.П. Ковтун, Д.О. Солопіхін, Ю.В. Горбенко, Т.Н. Рудичева, \\ Д.Г. Малихін, І.В. Колодій, В.Д. Вірич
}

Розроблено беззатравочний процес отримання високочистих монокристалів Zn методом вертикальної направленої кристалізації (ВНК) із розплаву. Вихід монокристалічної структури становить від 60 до $80 \%$. Отримано кристали з різним напрямком зростання: [1015] і [0002]. Кути відхилення напрямку росту відносно осі стержнів складають $0,5 \ldots 6^{\circ}$. Визначені мікротвердість, кристалічна досконалість монокристалів і мікроструктура. Досліджено домішковий склад початкової і кінцевої частин монокристалів, отриманих з вихідних марок цинку різної чистоти. Розроблений процес може бути використаний для вирощування монокристалів легкоплавких металів, таких як $\mathrm{Cd}, \mathrm{Pb}, \mathrm{Te}, \mathrm{In}, \mathrm{Bi}, \mathrm{Sn}$ i iн. 